\title{
OUTDOOR PARTICULATE MATTER (PM) AND ASSOCIATED CARDIOVASCULAR DISEASES IN THE MIDDLE EAST
}

\author{
ZEINA NASSER ${ }^{1,2}$, PASCALE SALAMEH ${ }^{3}$, WISSAM NASSER ${ }^{4}$, LINDA ABOU ABBAS ${ }^{1}$, ELIAS ELIAS, \\ and ALAIN LEVEQUE ${ }^{1}$
}

${ }^{1}$ Free University of Brussels, Brussels, Belgium

Research Center in Epidemiology, Biostatistics and Clinical Research, School of Public Health

${ }^{2}$ Lebanese University, Beirut, Lebanon

Clinical and Epidemiological Research Laboratory (LCER), Doctorate School of Sciences and Technology

${ }^{3}$ Lebanese University, Beirut, Lebanon

Clinical and Epidemiological Research Laboratory (LCER), Faculty of Pharmacy

${ }^{4}$ Ministry of Public Health, Beirut, Lebanon

Epidemiological Surveillance Unit

${ }^{5}$ American University of Beirut, Beirut, Lebanon

Department of Surgery, Division of Neurosurgery

\begin{abstract}
Air pollution is a widespread environmental concern. Considerable epidemiological evidence indicates air pollution, particularly particulate matter (PM), as a major risk factor for cardiovascular diseases (CVD) in the developed countries. The main objective of our review is to assess the levels and sources of PM across the Middle East area and to search evidence for the relationship between PM exposure and CVD. An extensive review of the published literature pertaining to the subject (2000-2013) was conducted using PubMed, Medline and Google Scholar databases. We reveal that low utilization of public transport, ageing vehicle fleet and the increasing number of personal cars in the developing countries all contribute to the traffic congestion and aggravate the pollution problem. The annual average values of PM pollutants in the Middle East region are much higher than the World Health Organization 2006 guidelines $\left(\mathrm{PM}_{25}=10 \mu \mathrm{g} / \mathrm{m}^{3}, \mathrm{PM}_{10}=20 \mu \mathrm{g} / \mathrm{m}^{3}\right)$. We uncover evidence on the association between PM and CVD in 4 Middle East countries: Iran, Kingdom of Saudi Arabia, Qatar and the United Arab Emirates. The findings are in light of the international figures. Ambient PM pollution is considered a potential risk factor for platelet activation and atherosclerosis and has been found to be linked with an increased risk for mortality and hospital admissions due to CVD. This review highlights the importance of developing a strategy to improve air quality and reduce outdoor air pollution in the developing countries, particularly in the Middle East. Future studies should weigh the potential impact of PM on the overall burden of cardiac diseases.
\end{abstract}

Key words:

Air pollution, Particulate matter, $\mathrm{PM}_{2.5}, \mathrm{PM}_{10}$, Cardiovascular diseases, Middle East

Received: January 8, 2014. Accepted: December 18, 2014.

Corresponding author: Z. Nasser, Lebanese University, Doctorate School of Sciences and Technology, Clinical and Epidemiological Research Laboratory (LCER), Rafic Hariri Campus, Hadath, Beirut 6573-14, Lebanon (e-mail: znasser@ulb.ac.be). 


\section{BACKGROUND}

Due to the growing pace of urbanization and industrialization, air pollution is an increasing problem related to human health. Because of the health hazard it poses it has been studied in industrialized countries since the mid-20th century [1]. Traffic-related air pollution (TRAP) is a major source of the outdoor air pollution. It is a serious problem particularly in numerous cities of the developing countries, where due to the exhaust emissions of motor vehicles and the combustion of poor quality fossil fuels, air quality is getting worse and worse. The phenomenon of temperature inversion in cold seasons is another factor contributing to the outdoor air pollution [2]. The available published literature indicates that air pollution is extensively researched due to its link with different toxic compounds of ambient air, such as carbon monoxide $(\mathrm{CO})$, ozone $\left(\mathrm{O}_{3}\right)$, nitrogen oxide $\left(\mathrm{NO}_{\mathrm{x}}\right)$, sulfur dioxide $\left(\mathrm{SO}_{2}\right)$ and particulate matter (PM) [3].

In fact, the United Nations and the World Health Organization (WHO) have announced that particulate matter (PM) constitutes the greatest international air pollution threat [4]. Particulate matter consists of mixed solid and liquid aerosol particles that differ in size and chemical composition [5], and it is divided into: coarse $\left(\mathrm{PM}_{10-2.5}=10-2.5 \mu \mathrm{m}\right)$, fine $\left(\mathrm{PM}_{2.5}<2.5 \mu \mathrm{m}\right)$, and ultrafine $\left(\mathrm{PM}_{01}<0.1 \mu \mathrm{m}\right)$ particles. Thousands of chemicals have been detected in PM including sulfates, nitrates, elemental and organic compounds, polyciclic aromatic hydrocarbons and some metals such as iron, copper, nickel, zinc, and vanadium. Particulate matter particles are either of anthropogenic origin - they come mainly from motor vehicle emissions, road dust, power generation, industrial combustion, construction and demolition activities, or of natural origin such as sea salt, volcanic emissions and naturally suspended dust [6].

Particle size and chemical composition of PM determine the health risk it poses [5]. Until recently, special attention has been paid to the ultrafine and/or soluble PM constituents. Due to their small size, these particles are inhaled deeply into the lungs where they can reach alveoli of the lungs, enter the pulmonary circulation and even pass into the systemic blood vasculature [5,7].

The incidents of noticeably increased death rates that occurred during the unusual exceedances of urban pollution in Belgium in 1930 [8] and during the fog incident in London in 1952 [9] initiated the 1st epidemiological research about the relationship between PM and health risks.

During the past 2 decades, there have been consistent trials to detect the association between ambient air pollution levels and the increased morbidity and mortality [1,10-15]. According to WHO, air pollution is estimated to be responsible for about 1 million deaths worldwide [16].

Over the past few years, a series of observational and epidemiological research studies in the developed countries have increasingly sought to understand and explore the influence of environmental determinants on cardiovascular system, with special emphasis on ambient PM [17-21]. Cardiovascular diseases (CVD), which influence heart and blood vessels, are the leading cause of mortality and morbidity worldwide [22]. The CVD mainly include coronary heart disease, stroke and hypertension [23], whereas tobacco consumption, hypertension, high cholesterol level, diabetes, physical inactivity and poor diet constitute the major risk factors for $\mathrm{CVD}[23,24]$.

A substantial rise in the occurrence of life-threatening myocardial infarctions [25] and cardiac arrhythmias [26] has been recorded after exposure to high atmospheric $\mathrm{PM}_{2.5}$ levels. Furthermore, development of ischemic cardiovascular episodes through triggering myocardial infarction as well as exacerbation of coronary artery disease and atherosclerosis have been noticed following hours of exposure to ambient PM [27].

Particulate matter pollution is also associated with an increased risk of myocardial infarction in older population [28], acute cardiac decompensation in heart failure 
patients [29], a greater increase in the rate of hospital admissions due to exacerbation of congestive heart failure [30] as well as to cardiovascular and respiratory diseases [31].

While considerable epidemiological evidence indicates outdoor air pollution, principally PM, as a major risk factor for CVD in the developed countries [4,6,32], there is limited research on this association in the developing countries, especially in the Middle East region. The main objective of our comprehensive article review is to assess the levels and sources of PM across this geographic area and to search evidence for the relationship between PM exposure and CVD whenever literature pertaining to the subject is available.

\section{Biological mechanism linking PM with CVD}

The diverse biological pathways through which inhalation of PM into the lungs could be capable of triggering unfavorable effects on the cardiovascular system constitute the major issue to be addressed.

The ultrafine particles and/or soluble PM constituents may rapidly enter pulmonary alveoli of the lungs after inhalation and, subsequently, pass into the systemic blood circulation imposing its adverse inflammatory effects on the cardiovascular system.

Another alternative pathway suggests that, following their inhalation, PM particles induce a pulmonary oxidative stress effect that might trigger systematic prooxidative and pro-inflammatory chain reactions and the release of pro-inflammatory mediators, activated leucocytes, cytokines (e.g., interleukin-6) and C-reactive protein from the pulmonary to the systemic circulation. These chemicals and pro-inflammatory mediators might, in turn, indirectly trigger adverse cardiovascular events summarized by endothelial dysfunction, cardiovascular oxidative stress, cardiovascular inflammation, acute myocardial infarctions, cardiac heart failure and chronic atherosclerosis [33-43].

\section{MATERIAL AND METHODS}

This is a comprehensive review of the literature from the period extending from 2000 till 2013. It includes reports, scientific studies, books, reviews, international conferences and other literature resources concerning PM levels, its sources and its association with CVD in the Middle East countries. Further details are presented in Figure 1.

Literature search was performed by means of electronic databases (Pubmed, Medline, and Google Scholar) and by manual search for all the relevant references in the literature using a combination of keywords such as: air pollution, particulate matter, PM, cardiovascular disease, CVD, myocardial infarction, MI, heart rate variability, atherosclerosis, Middle East, Bahrain, Egypt, Iran, Iraq, Jordan, Kuwait, Lebanon, Oman, Palestine, Qatar, Saudi Arabia, Syria, Turkey, United Arab Emirates and Yemen. The keywords were combined using the Boolean operators "or" and "and."

Bibliography lists from all the eligible articles were also searched manually to identify and supplement additional papers potentially relevant for inclusion. All the studies evaluating the mean concentrations of PM and investigating association between PM and CVD in the Middle East were included. The studies which were not carried out on human subjects or not drafted in English were excluded.

\section{Findings}

Influenced by photochemical air pollution [44] and dust storm activities $[45,46]$, the Middle East is currently encountering a serious environmental problem. The major contributors to the outdoor air pollution in this region are: anthropogenic activities, which are constantly increasing due to the rapid growth in urban populations, and expansion of industrial sites [47].

In fact, PM levels in the Eastern Mediterranean region are much higher than in other regions, even when compared to the Western Mediterranean region [48]. Although there is enough evidence on the association between the outdoor 


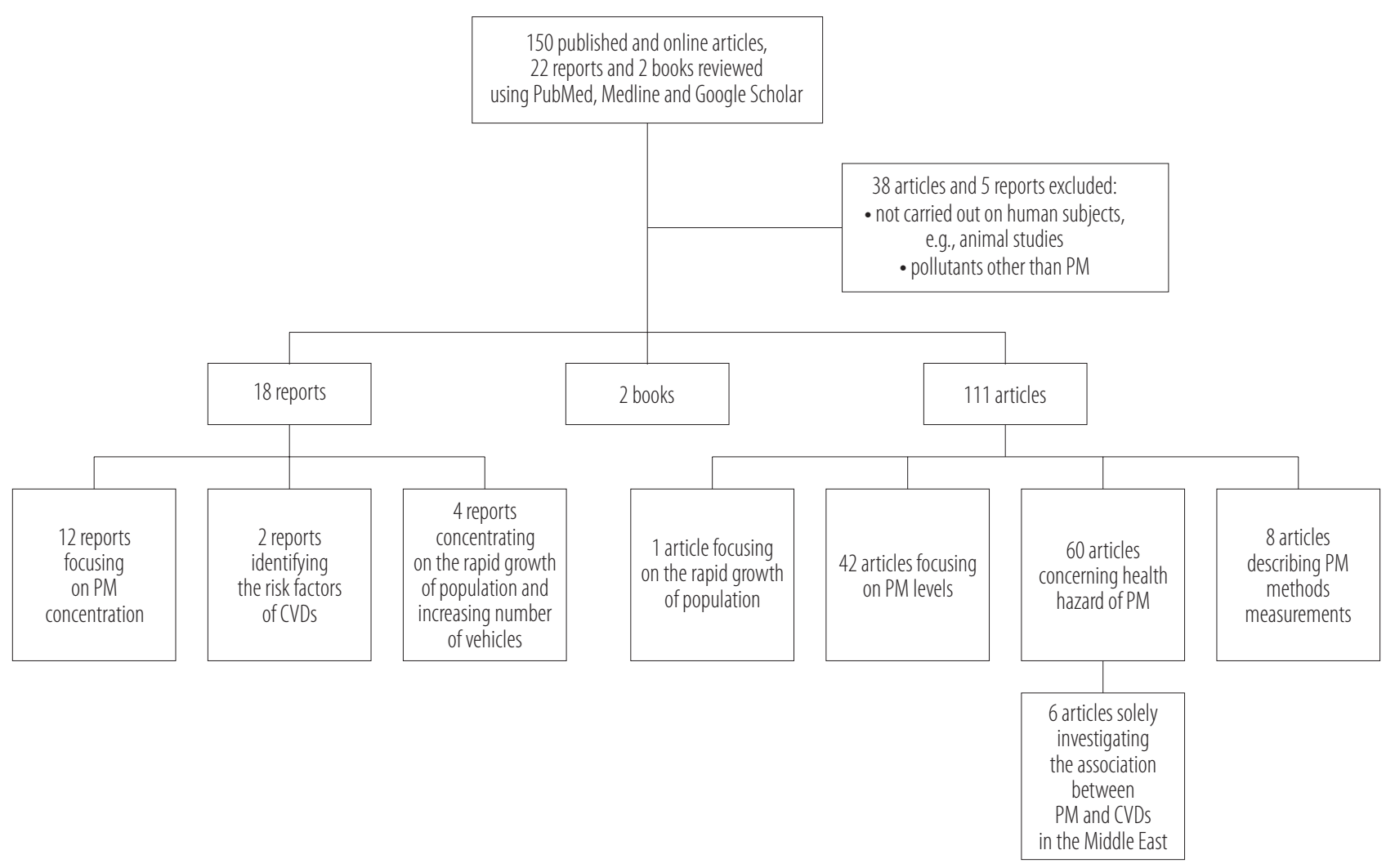

PM - particulate matter; CVD - cardiovascular disease.

Fig. 1. Flowchart of the studies relevant for the review

air pollution and CVD in the developed countries, the studies investigating this association in the Middle East are rather limited. Our findings enabled to point out only selected countries of the Middle East in this article review.

Outdoor PM levels, sources of air pollution

and the association with CVD in the Middle East

Egypt

Cairo, the capital of Egypt with more than 15 million population [49], suffers from high concentrations of ambient pollutants, including: carbon monoxide, nitrogen oxides, sulfur dioxide, ozone and PM [50,51].

The phenomenon of thermal inversion further facilitates accumulation of atmospheric air pollutants emitted from different sources due to the slow wind movement and low temperature during cold seasons in Egypt [52]. Moreover, lack of rain and city layout characterized by narrow streets and tall buildings cause poor dispersion of pollutants over Cairo [49]. According to WHO, PM is the most common air pollutant in urban and industrial areas in Egypt [53]. In fact, almost $36 \%$ of atmospheric $\mathrm{PM}_{2.5}$ is attributed to onroad traffic where more than 1 million cars, particularly older ones with poor technical specifications, circulate on the roads of Cairo. Other sources, namely open burning and residential combustion, contribute mainly to the remaining 54\% of atmospheric $\mathrm{PM}_{2.5}$ [49].

Zakey has presented the mass concentrations of $\mathrm{PM}_{2.5}$ and $\mathrm{PM}_{10}$ and exposed their seasonal variations from samples collected at 17 different sites, representing urban, industrial, residential and background (with a significant agriculture activity) sectors in the Greater Cairo (GC) over the period 2001-2002. 
Egyptian law of environment has not yet established an annual limit for $\mathrm{PM}_{10}$ concentration, however, the concentrations of $\mathrm{PM}_{2.5}$ and $\mathrm{PM}_{10}$ measured in this study were generally high, with annual average values of $85 \pm 12 \mu \mathrm{g} / \mathrm{m}^{3}$ and $170 \pm 25 \mu \mathrm{g} / \mathrm{m}^{3}$, respectively, exceeding the WHO recommended guideline annual averages of $10 \mu \mathrm{g} / \mathrm{m}^{3}$ and $20 \mu \mathrm{g} / \mathrm{m}^{3}$ for $\mathrm{PM}_{2.5}$ and $\mathrm{PM}_{10}$ [54].

It is believed that the combined effect of anthropogenic emissions (traffic and waste burning) and the transport of dust by wind from Moqattam hill and the desert to GC contribute to the obserwed high PM levels. The urban sector recorded the highest $\mathrm{PM}_{2.5} / \mathrm{PM}_{10}$ ratio $(0.59)$ compared to the residential sector $(0.32)$. The recorded seasonal PM concentrations were the highest in the spring season at the industrial sectors, whereas these concentrations were the lowest during the summer at the background sites [55].

Another study was carried out to assess the source attribution of different ambient PM levels measured on 24-h basis at 6 sampling sites of Greater Cairo area representing industrial, traffic, residential and background conditions during 3 separate periods between February 1999 and June 2002. The samples were collected using the sampling protocol designed by Watson et al. [56]. Then, the Chemical Mass Balance (CMB) receptor model was used to allocate PM and its chemical constituents to their sources [57]. In this study, the $\mathrm{PM}_{10}$ mass concentration during the summer period of 2002 ranged between $99.2 \pm 5 \mu \mathrm{g} / \mathrm{m}^{3}$ in El-Zamalek (residential) to $175.3 \pm 9.1 \mu \mathrm{g} / \mathrm{m}^{3}$ in ElMaa'sara, an industrial site influenced by dust emissions from the surrounding cement factories. The $\mathrm{PM}_{2.5}$ mass concentration varied between $34.7 \pm 1.9 \mu \mathrm{g} / \mathrm{m}^{3}$ in Kaha (background) to $60.7 \pm 3.2 \mu \mathrm{g} / \mathrm{m}^{3}$ in Shobra, an industrial location with numerous nearby lead smelters. This study has also revealed that $\mathrm{PM}_{2.5}$ is mainly attributed to a mobile source and open burning emissions. On top of these sources, emissions from geological material were also a major contributor to $\mathrm{PM}_{10}[51]$.
Iran

The capital city of Iran - Tehran - is one of the worst cities in the world in terms of air pollution. About 1.5 million tons of pollutants from different sources, particularly suspended particles, are produced in Tehran annually [58,59]. One major factor contributing to the air pollution is the highly populated city of Tehran where around 13\% (9 millions) of the total country's population lives, and where emissions from motor vehicles are responsible for the $70 \%$ of air pollution in this city. Temperature inversion is another factor contributing to air pollution, particularly in cold seasons [60]. During these seasons, PM as the major air pollutant of Tehran's air is increased [61].

The annual average of $\mathrm{PM}_{10}$ concentrations in Tehran was 1.3 times the world's average $\left(71 \mu \mathrm{g} / \mathrm{m}^{3}\right)$ [62] and 4.5 times the WHO recommended guideline annual average values of $10 \mu \mathrm{g} / \mathrm{m}^{3}$ for $\mathrm{PM}_{2.5}$ and $20 \mu \mathrm{g} / \mathrm{m}^{3}$ for $\mathrm{PM}_{10}$ [54].

A study conducted in 2010 compared the mass and number concentrations of $\mathrm{PM}_{10}, \mathrm{PM}_{2.5}$, and $\mathrm{PM}_{1.0}$ in the westcentral parts of Tehran during 2 consecutive warm and cold seasons. This study has shown that, in cold seasons, the $\mathrm{PM}_{10}$ mass concentration increased almost 2 folds and $\mathrm{PM}_{2.5}$ and $\mathrm{PM}_{1.0}$ nearly 3 times. The mean number concentration of these particles was found to be almost 4.8 times in the same season [61]. This could be attributed to the Tehran's geographical position being edged by mountains from the north, and to the fact that the wind is cold and slow, which makes air pollutants become trapped over Tehran [61-63].

A major finding of the study by Poursafa et al. in 2010 suggested PM to have impact on the platelet activation and atherosclerosis, which are associated with CVD [64]. In the same year, Davoodi et al. [65] examined the association between changes in the heart rate variability and exposure to air pollution in Tehran. During air pollution episodes, the maximum heart rate was significantly lower as compared to the clear air conditions 
$\left(115.1 \pm 32.2 \mu \mathrm{g} / \mathrm{m}^{3}\right.$ vs. $\left.128.9 \pm 17.7 \mu \mathrm{g} / \mathrm{m}^{3}\right)$. The occurrence of non-sustained supraventricular tachycardia, as a marker of cardiac dysfunction, was recorded in almost $43 \%$ of the participants during the polluted air conditions, whereas this arrhythmia was not reported during the non-polluted conditions ( $p=0.001)$ [65].

A major aspect in the development of early-life atherosclerosis is the relationship of air pollution with endothelial dysfunction and pro-coagulation effect. A cross-sectional study was conducted between 2009 and 2010 in Isfahan, one of the largest cities of Iran, to assess the relationship of air pollutants with plasma surrogate markers of endothelial dysfunction tissue factor (TF) and thrombomodulin (TM) in children. The observed mean $\mathrm{PM}_{10}$ level was notably high, exceeding the normal level $\left(120.48 \mu \mathrm{g} / \mathrm{m}^{3}\right.$ vs. $50 \mu \mathrm{g} / \mathrm{m}^{3}$ ) [66].

Furthermore, a very recent study has provided quantitative estimates of the impact of a short-term exposure to specific atmospheric pollutants on the health of population living in Tehran city from January 2010 to January 2011. The health impact of PM exposure on Tehran people's health was assessed using the Air Quality Health Impact Assessment (Air Q 2.2.3) software created by the WHO European Centre for Environment Health, Bilthoven Division [67]. Air concentrations of PM pollutants in the capital were quantified by the Tehran Air Quality Control Corporation (TAQCC). According to this study, the annual mean $\mathrm{PM}_{10}$ level in Tehran was $90.58 \mu \mathrm{g} / \mathrm{m}^{3}$. On average, 1367 extra total deaths and 2580 extra cases admitted to hospitals due to CVD annually were attributable to the increase by $10 \mu \mathrm{g} / \mathrm{m}^{3}$ in $\mathrm{PM}_{10}$ levels [63].

\section{Jordan}

Air pollution in Jordan has become an increasing problem since the past 2 decades. This is partly attributed to the rapid growth of the Jordanian population where about $40 \%$ of the total inhabitants live in the capital Amman [68]. Nevertheless, the major source of air pollution in Amman is motor vehicle emissions with more than $80 \%$ of the 1 million registered vehicles in Jordan found in this city [69]. A cross-sectional study was conducted in order to examine the link between the traffic-related air pollutants (TRAP), particularly $\mathrm{PM}_{10}$ and total suspended particulates (TSP), and vehicle traffic in Amman in 2010 in 2 high-polluted and 2 low-polluted random areas with relatively similar demographic and climatic characteristics [68]. Total suspended particulates and $\mathrm{PM}_{10}$ were measured as ambient air concentrations by the Jordanian Air Quality Monitoring Department using the respirable dust high-volume sampler method. High levels of $\mathrm{PM}_{10}$ and TSP were observed in the areas with dense vehicle traffic. The mean $\mathrm{PM}_{10}$ concentration in the high-polluted areas was significantly higher $\left(164.9 \pm 58.7 \mu \mathrm{g} / \mathrm{m}^{3}\right)$, than that in the low-polluted areas $\left(90.9 \pm 34.4 \mu \mathrm{g} / \mathrm{m}^{3}\right)$, exceeding the Jordanian standard for $\mathrm{PM}_{10}$ of $120 \mu \mathrm{g} / \mathrm{m}^{3}$ [68].

\section{Kingdom of Saudi Arabia}

Air pollution in the Kingdom of Saudi Arabia has recently become a public health concern due to the rapid population growth and the increased economic expansion associated with fuel over-consumption. According to Khodeir et al. [70], there is no published systematic research on the sources of atmospheric PM in Jeddah, the 2nd largest city and the most significant commercial center in the Kingdom of Saudi Arabia, with an estimated population of 3.4 million. Desert storms are frequent in Jeddah and contribute to the most of PM in this area [70]. A study was conducted between June and September 2011 to evaluate mass concentrations of $\mathrm{PM}_{2.5}$ and $\mathrm{PM}_{10}$ and their sources in multiple sites in Jeddah using the nondestructive X-ray Fluorescence (XRF) Spectrometer [71]. The results have revealed that the airborne particulate pollution was high in this city, and that the major sources of $\mathrm{PM}_{2.5}$ or $\mathrm{PM}_{10}$ included diverse industrial activities, fuel combustion and traffic emissions. The overall average mass concentrations were: $28.4 \pm 25.4 \mu \mathrm{g} / \mathrm{m}^{3}$ for $\mathrm{PM}_{2.5}$ 
and $87.3 \pm 47.3 \mu \mathrm{g} / \mathrm{m}^{3}$ for $\mathrm{PM}_{10}$, exceeding the WHO annual average values [70].

Another study conducted from June 2006 to May 2007 in the capital Riyadh, using the same methodology as the one described above [71], has determined PM concentrations in the aerosol samples collected on rooftops of buildings from different sectors of the city. Concentration of $\mathrm{PM}_{10}$ was approx 1-4 times higher than that of $\mathrm{PM}_{2.5}$. The recorded concentrations of PM in 2007 were higher than in 2006, probably as a consequence of the intense development activities in Riyadh. The southeast sector of Riyadh presented the highest levels of $\mathrm{PM}_{2.5}\left(257.6 \mu \mathrm{g} / \mathrm{m}^{3}\right)$, and $\mathrm{PM}_{10}\left(597.2 \mu \mathrm{g} / \mathrm{m}^{3}\right)$ where mixed industrial activities, mostly ceramic, cement and stone cutting, were the major sources contributing to the local dust. According to this study, it was obvious that the environment of Riyadh was severely polluted [72].

A recent paper by Sun et al. in 2012 has found that more than 1.5-fold significant changes in genes related to oxidative stress, cholesterol and lipid synthesis pathways were triggered following the short- (1 day) and longterm (4-days) exposure of human bronchial epithelial cells to $\mathrm{PM}_{10}$ samples collected from the Kingdom of Saudi Arabia. These changes may contribute to respiratory diseases and CVD related to PM [73].

\section{Kuwait}

The environment of Kuwait, a desert country located on the Persian Gulf, was severely polluted from the 19901991 due to Iraqi invasion and subsequent oil fires [74].

Alolayan et al. have investigated other sources contributing to particulate air pollution in this country. Sand dust and oil combustion power plants were the first 2 major sources contributing to fine particles $\mathrm{PM}_{2.5}$ in Kuwait accounting for almost $54 \%$ and $18 \%$ of the total atmospheric $\mathrm{PM}_{25}$, respectively. Meanwhile, the petrochemical industry, traffic and transported emissions from the outside of this country contributed to the remaining $28 \%$ of the total $\mathrm{PM}_{2.5}[75]$.
A12-month study was conducted to measure mean concentrations of $\mathrm{PM}_{10}$ and $\mathrm{PM}_{2.5}$ in 3 areas (2 urban-central and southern- and 1 remote desert-northern) in Kuwait during the period 2004-2005. The results showed that the annual mean $\mathrm{PM}_{10}$ concentration varied between $66 \mu \mathrm{g} / \mathrm{m}^{3}$ and $93 \mu \mathrm{g} / \mathrm{m}^{3}$ across the 3 areas, exceeding the recommended WHO air quality guidelines. Moreover, the annual mean concentration of $\mathrm{PM}_{2.5}$ ranged from $37 \mu \mathrm{g} / \mathrm{m}^{3}$ to $38 \mu \mathrm{g} / \mathrm{m}^{3}$ in the southern and central areas, respectively, and $31 \mu \mathrm{g} / \mathrm{m}^{3}$ in the northern area [76].

During the same period, Al Salem [77] analyzed the ambient $\mathrm{PM}_{10}$ levels in Fahaheel, a typical urban area in Kuwait, using the semi-empirical model described by Grivas et al. [78]. The annual mean concentration was 291 and $289 \mu \mathrm{g} / \mathrm{m}^{3}$ in 2004 and 2005, respectively [77]. It was also mentioned in the published literature that so far there has been no specific study that would explore the link between deteriorating air quality and health problems in Kuwait [79].

\section{Lebanon}

Lebanon, a small developing country located in the Eastern Mediterranean region, experiences high pollution episodes mainly attributed to vehicle-induced emissions. This situation is further aggravated by the rapid growth of population, the old-aged vehicles operating on gasoline, and the lack of a public transport system [45,80-85].

Furthermore, dust storms originating from the Saharan desert influence Lebanon during the fall and spring seasons, which leads to the increase in coarse air pollutants [84-86]. Higher levels of fine particulates are also observed in the summer due to the increased humidity and photo-chemically induced secondary PM [84].

Shaka et al. [87] measured PM concentrations in a costal site in Beirut, the capital of Lebanon, between February and May 2003. Particulate matter 10-2.5 and $\mathrm{PM}_{2.5}$ collected on Teflon filters [88] were weighed using the Cahn microgram balance model 1500 and analyzed 
using the Nicolet AVATR Multibounce HATR 360 FTIR spectrometer. In this study, the 4-month average concentrations reported for $\mathrm{PM}_{2.5}$ and $\mathrm{PM}_{10}$ of $39.9 \mu \mathrm{g} / \mathrm{m}^{3}$ and $118.8 \mu \mathrm{g} / \mathrm{m}^{3}$, respectively, were very similar to those reported in the Eastern Mediterranean countries but higher than those in the Western Mediterranean ones [87]. Saliba et al. [84] have studied several years of PM measurements and their chemical composition in several sites of the Greater Beirut area (Haret Hreik HH: urban area, post war 2006 construction activities and inner-city site; Bourj Hammoud BH: urban area, close to Beirut harbor and a waste burning facility, and inner-city site; Abdl Aziz, Bliss and Seagate: urban areas and costal sites). PM concentrations were collected on Teflon filters and weighed using the Mettler-Toledo microgram balance (model UMX2).

The average concentrations in different sites of the Greater Beirut area from 2003 to 2007 ranged: $55.1-103.8 \mu \mathrm{g} / \mathrm{m}^{3}$ for $\mathrm{PM}_{10}$ and 27.6-41 $\mu \mathrm{g} / \mathrm{m}^{3}$ for $\mathrm{PM}_{2.5}$ [84]. The reported levels exceeded the 2006 WHO guidelines annual average values of 10 and $20 \mu \mathrm{g} / \mathrm{m}^{3}$ [54]. In particular, populated and inner-city sites like Haret Hreik and Bourj Hammoud showed higher PM levels than those of coastal sites. The study results have suggested that the large quantities of coarse particles detected in Haret Hreik could be attributed to the construction period that followed the July 2006 conflict [84].

In fact, it has been frequently reported in the published literature that construction activities are a major source of $\mathrm{PM}_{10}$ and not $\mathrm{PM}_{2.5}$ [51,89-92]. More recently, high annual concentrations of $\mathrm{PM}_{2.5}$ and $\mathrm{PM}_{10}$ of $20 \mu \mathrm{g} / \mathrm{m}^{3}$ and $64 \mu \mathrm{g} / \mathrm{m}^{3}$, respectively, were recorded in the capital Beirut between May 2009 and April 2010 [81].

\section{Qatar}

Expanding motor vehicle traffic and industrialization in the state of Qatar constitute the major source of air pollution [93]. The national average concentration values of $\mathrm{PM}_{10}$ in Qatar had declined from $47 \mu \mathrm{g} / \mathrm{m}^{3}$ in 2000 to $31 \mu \mathrm{g} / \mathrm{m}^{3}$ in 2009 [94]. Nevertheless, in the capital Doha, the average $\mathrm{PM}_{10}$ levels in 2010 at some points exceeded the annual limit recommended by WHO [54] as a result of the combination of dust from desert storms and megaconstructions activities $[94,95]$.

A prospective cohort study population was conducted to assess the relationship between daily hospital admissions due to respiratory and CVD and the exposure to daily concentrations of air pollutants - carbon monoxide (CO), sulfur dioxide $\left(\mathrm{SO}_{2}\right)$, nitrates, ozone $\left(\mathrm{O}_{3}\right)$ and $\mathrm{PM}_{10}$ at different stations of Qatar during the period 2002-2005. The slight increase observed in the concentrations of these air pollutants in the year 2005 was consistent with a similar increase in the daily hospital admissions due to respiratory, ischemic heart diseases and CVD. It is apparent from this study that the rise in pollutant levels was associated with an increased hospital admissions for both respiratory diseases and CVD [93].

\section{Syria}

Dry climate and the rapidly growing developing urban population (about 4-5 million) characterize the capital of Syria, Damascus. The main air quality problems in Damascus city are related to the increased use of motor vehicles, particularly ageing ones in service and the poor quality diesel. To report the air quality situation in Damascus within the framework of bilateral cooperation between Syria and Germany from 19992000, Meslmani examined 15 selected sites representing different areas of Damascus city. Particulate matter 10 was measured by the use of gravimetric methods using the high volume air sampler (HVAS), TRACERLAB Model MDS-170-257. The resulting 24-h average concentration of $\mathrm{PM}_{10}$ in Damascus varied between $44 \mu \mathrm{g} / \mathrm{m}^{3}$ and $188 \mu \mathrm{g} / \mathrm{m}^{3}$. This study also reported that $\mathrm{PM}_{10}$ and TSP were the most effective pollutants in the air of Damascus city [96]. 


\section{Turkey}

Istanbul, a highly populated capital of Turkey, with more than 12 million inhabitants, has demonstrated an excessive urban growth since 1970s [49,97]. In fact, atmospheric PM is one of the serious concerns of Istanbul where road traffic contributes to the highest proportion of local emissions [91]. Transit route transport from Eastern Europe is of equal importance $[98,99]$.

The annual mean $\mathrm{PM}_{10}$ and $\mathrm{PM}_{2.5}$ levels collected on the gent stacked filter unit and measured using the gravimetric method [100] between the years 2001 and 2002 in Erdemli, a rural area in Turkey located in the Eastern Mediterranean region, were $36.4 \pm 27.8 \mu \mathrm{g} / \mathrm{m}^{3}$ and $9.7 \pm 5.9 \mu \mathrm{g} / \mathrm{m}^{3}$, respectively [91].

Karaca et al. [101] have measured the annual mean $\mathrm{PM}_{10}$ and $\mathrm{PM}_{2.5}$ concentrations from the 86 daily aerosol samples collected during the period between July 2002 and July 2003 at several municipality stations in Istanbul. The recorded $\mathrm{PM}_{10}$ value of $47.1 \mu \mathrm{g} / \mathrm{m}^{3}$ and $\mathrm{PM}_{2.5}$ value of $20.8 \mu \mathrm{g} / \mathrm{m}^{3}$ [101] were higher than the WHO recommended levels [54].

Another study by Yatkin and Bayram [102] in 2008 showed that the annual mean of $\mathrm{PM}_{2.5}$ and $\mathrm{PM}_{10}$ in urban Izmir in Turkey during the period 2004-2005 was $64 \mu \mathrm{g} / \mathrm{m}^{3}$ and $80 \mu \mathrm{g} / \mathrm{m}^{3}$, respectively. The $\mathrm{PM}_{10}$ and $\mathrm{PM}_{2.5}$ samples were determined using the chemical mass balance model (CMB) [102].

Also, Theodosi et al. [103] have analyzed the complete chemical composition of different aerosol samples (water-soluble ions, trace metals, water-soluble organic carbon, organic and elemental carbon) collected at the Bogaziçi University sampling station in Bosphorus strait in the Greater Istanbul Area from November 2007 to June 2009. The measured $\mathrm{PM}_{10}$ concentration was $39.1 \mu \mathrm{g} / \mathrm{m}^{3}$ [103].

A supplementary study by Koçak et al. [105] has examined the origin, source and potential impact of $\mathrm{PM}_{10}$ on surrounding regions over the Greater Istanbul Area for the same period. This study indicates that $80 \%$ of $\mathrm{PM}_{10}$ originate from anthropogenic sources, largely fuel oil combustion, refuse incineration and traffic emissions. The mean $\mathrm{PM}_{10}$ level collected on the polycarbonate filters and analyzed using the gravimetric method [104], was the highest in the winter $\left(44.5 \mu \mathrm{g} / \mathrm{m}^{3}\right)$, lesser during the transitional period, and the lowest in the summer $\left(29.8 \mu \mathrm{g} / \mathrm{m}^{3}\right)$ [105].

\section{United Arab Emirates}

Outdoor air pollution is an increasing problem in the United Arab Emirates (UAE), a place of common and severe dust storms and a home to large industries, where deteriorating air quality can be easily detected through the degraded visibility [106]. The rapidly growing population in the UAE reflected by its increase in size from less than 400000 to nearly 4.4 million is yet another environmental concern [107,108].

The 2 major urban cities, Abu Dhabi and Dubai, contribute to massive vehicular emissions and traffic congestion [106]. These 2 centers experience extremely high PM concentrations, particularly $\mathrm{PM}_{10}$ that originates mainly from windblown desert dust [109]. The average annual exposure level to urban outdoor $\mathrm{PM}_{2.5}$ in the UAE was estimated to be $80 \mu \mathrm{g} / \mathrm{m}^{3}$ in 2010 [95]. A recent study has analyzed the daily $\mathrm{PM}_{10}$ mass concentrations collected from the Al Samha ambient air quality station, Abu Dhabi between 2007 and 2009. The mean daily $\mathrm{PM}_{10}$ concentration was $172 \pm 196 \mu \mathrm{g} / \mathrm{m}^{3}[110]$.

According to Li et al. [106], approximately 545 excess premature deaths (95\% confidence interval (CI): 132-1224] were attributable to PM in the ambient polluted air in the UAE in the year 2007, accounting for nearly $7 \%$ of the total deaths that year [106]. Additionally, 200 annual deaths in the UAE were attributed to $\mathrm{PM}_{10}$ in 2009 [111].

In 2013, MacDonald et al. [112] examined the burden of diseases attributable to 6 environmental exposure routes in the entire UAE population. This study has 
found that 307667 health-care facility visits due to CVD in 2008 were attributed to the outdoor daily average $\mathrm{PM}_{10}$ with a relative risk of 1.003 (95\% CI: 1.0024-1.0036) [112]. The results of annual $\mathrm{PM}_{10}$ concentrations, main sources of the outdoor air pollution and the presence of association with CVD in selected countries in the Middle East are reviewed in Table 1.

\section{DISCUSSION}

The current review summarizes atmospheric PM levels and the major sources of air pollution affecting environment in the selected countries of the Middle East, and it highlights their potential association with CVD.

Findings from this review manifest elevated PM concentrations in these countries, often exceeding the $2006 \mathrm{WHO}$ annual average guidelines $\left(\mathrm{PM}_{2.5} 10 \mu \mathrm{g} / \mathrm{m}^{3}\right.$, $\mathrm{PM}_{10} 20 \mu \mathrm{g} / \mathrm{m}^{3}$ ). This could be explained by several factors such as: high population density, rapid urbanization, dense traffic area, fossil fuel use, geographical settings of the region, frequent dusts outbreaks, temperature inversion during cold seasons, and the lack of rules and regulations concerning the reduction of emissions from anthropogenic (mobile and stationary) pollution sources.

As in many developing countries, traffic-related air pollution (TRAP) constitutes a primary anthropogenic source of air pollution affecting urban air quality in the Middle East. Some studies have estimated the contribution of TRAP to PM concentrations to be more than $50 \%$ in urban areas $[113,114]$. In fact, vehicle-induced emissions constitute a growing problem in this region due to the increase in traffic volume in the last decades $[45,68,80,81,83,115,116]$ and a large number of old vehicles combined with poor vehicle maintenance [117]. High levels of PM constitute a major public health concern in the affected countries and in the Middle East.

Studies from some developed countries have highlighted a strong association of air pollution with long- and shortcardiovascular morbidity and mortality [18,118-120]. Consistently with this study findings, 4 middle-eastern countries addressed in our review article (Iran, Kingdom of Saudi Arabia, Qatar and the United Arab Emirates), revealed an evidence of an association between air pollution, particularly PM, and CVD [63,66,73,93,112].

In this review, the results from these countries were presented in light of the international figures. Ambient PM pollution is considered a potential risk factor for platelet activation and atherosclerosis [121,122] and has been found to be linked with changes in the heart rate variability $[123,124]$ as a marker of cardiac autonomic dysfunction, and an increased risk for mortality and hospital admissions due to CVD [125-128].

On the other hand, the 6 remaining middle-eastern countries (Egypt, Jordan, Kuwait, Lebanon, Syria and Turkey) disclose a shortfall in reporting any associations between PM and cardiovascular diseases.

Urban outdoor air pollution is an inter-sectorial challenge. Major improvements in the air quality in the developed countries have occurred over the recent decades. There have been substantial achievements with respect to PM emissions in Europe. Between 2001 and 2010, direct emissions of $\mathrm{PM}_{10}$ and $\mathrm{PM}_{2.5}$ decreased by $14 \%$ in the European Union [129]. Being aware of the great contribution of road transport emissions to around $25 \%$ to $70 \%$ of the urban outdoor air pollution, depending on the city, many parts of Europe have enforced stricter standards and regulations for motor vehicles, such as substituting old vehicles by newer ones with more efficient engines, and using cleaner fuels [130].

With an objective to protect health of the USA population, the regulatory U.S. Environmental Protection Agency (EPA), which focuses on reducing air pollution at its many sources, particularly those exceeding the standards like ozone and PM, has set national Ambient Air Quality Standards (NAAQS) for pollutants [131].

Furthermore, the American Heart Association Scientific Statement on air pollution and cardiovascular disease has recommended the use of a daily Air Quality Index (AQI) to reduce exposure in persons with CVD [6]. Despite all 
these pronounced improvements in the air quality, the levels of outdoor air pollution continue to rise in the cities of the developed countries harming human health and the environment. In fact, high PM levels, exceeding the WHO recommendations on air quality guidelines, are still affecting a high proportion of European citizens posing a great health risk and affecting the quality of their life [130].

This review highlights the importance of developing a new control strategy to improve air quality and to reduce the outdoor air pollution which affects everyone, not only in the developed nations but also in the developing countries, particularly in the Middle East. Apart from the absence of any legislation that would punish polluters in this region, insufficient effort is made to implement convenient and practical alternative solutions for the outdoor air pollution due to human activities.

Considerable attention should be paid to the future expansion of towns and cities and related to it industrial emission sources, i.e., the absolute increase of motor vehicles on the road and its poor technical specification that does not comply with the latest international standards, the extensive use of poor quality fuel and inappropriate combustion activities.

Moreover, there is often lack of awareness and educational programs concerning health burden of the outdoor air pollution exposure within urban populations. This could be partly due to a gap in information regarding air quality monitoring that is restricted to certain areas in the Middle Eastern countries, or even due to an under-appreciation of the potential solutions and measures that can be taken to improve the quality of air.

Controlling or reducing anthropogenic sources of the outdoor air pollution would help clean the air we breathe, as well as minimize its health burden in the whole population.

\section{Limitations of the study}

Our review has few limitations. The lack of air monitoring stations in the majority of the Middle East countries results in reporting inaccurate PM levels for the whole geographical area. Furthermore, there are no national strategies in the Middle East countries aiming at assessment of the effect of air quality on the citizens' health. Another restraint of the study is the limited number of studies investigating association between PM and CVD in the Middle East countries despite yielding high pollutant concentrations.

We restricted our electronic database search to English literature, which might have failed to identify the grey literature, especially taking into consideration the fact that the native language of the majority of the population in this geographical region is Arabic. This has possibly excluded relevant eligible studies from our search.

Moreover, we should mention publications bias - the tendency for manuscripts with positive findings to be published more frequently than those with null findings. Last but not least, the biases and confounding factors inherent in the individual studies could not be controlled for and must be taken into consideration. Hence, future research probing the relationship between PM and CVD should attempt to overcome the limitations noted above. Moreover, study designs should be conducted to ascertain the causality of this relationship as well as the dose-response relationship and the biological mechanisms that link PM to cardiovascular diseases.

\section{CONCLUSIONS}

To our knowledge, this is the 1st review article carried out to investigate the presence of association between particulate matter (PM) and CVD in selected countries of the Middle East region. Despite the fact that our study revealed high levels of PM in the majority of this geographical areas, we only managed to uncovered 4 studies exploring detrimental PM-CVD relationship. Therefore, future studies should weigh the potential impact of PM on the overall burden of cardiac diseases. These findings have several important public health implications. Improving air quality standards, reducing personal exposures as well as the redesign of engines and fuel 


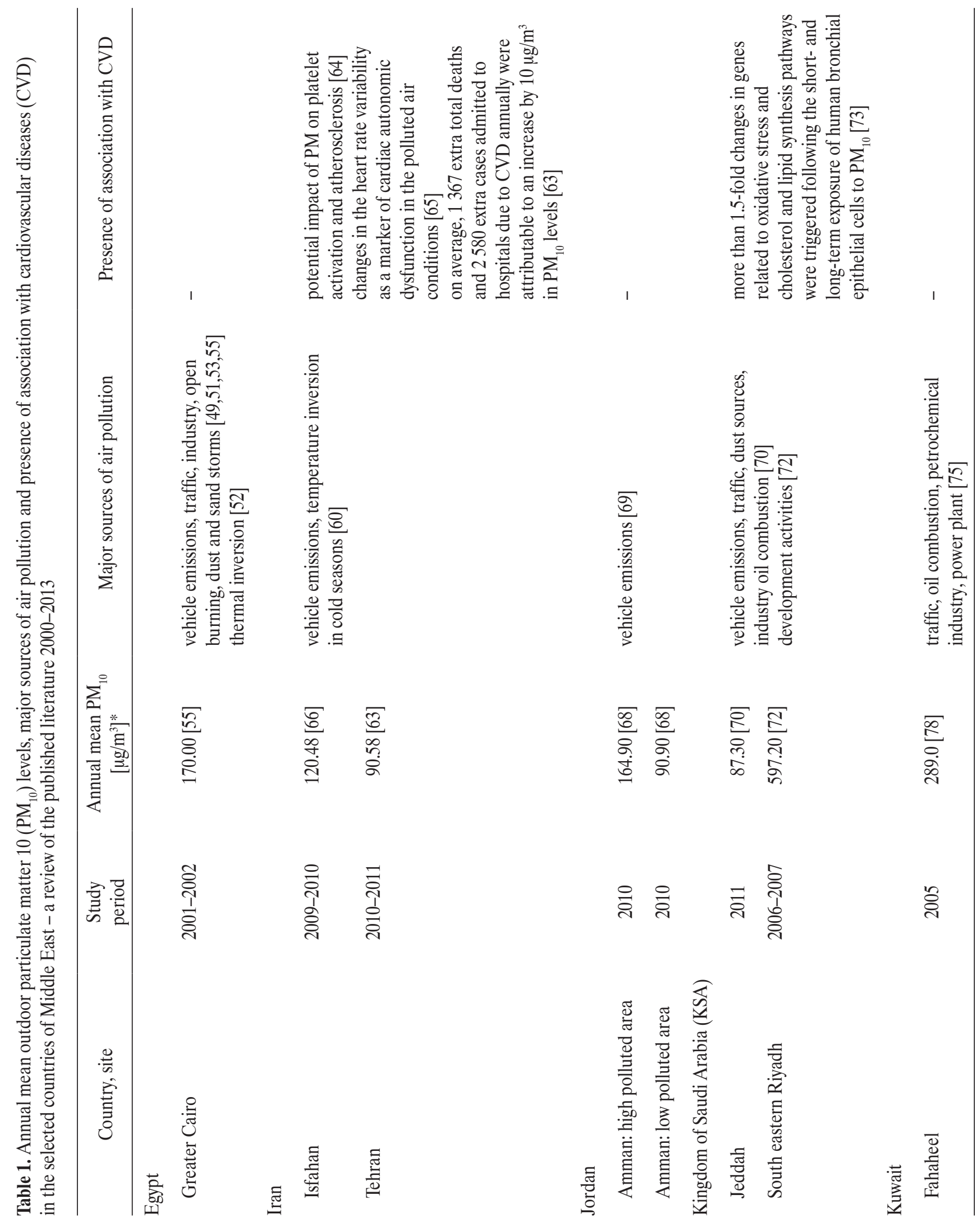




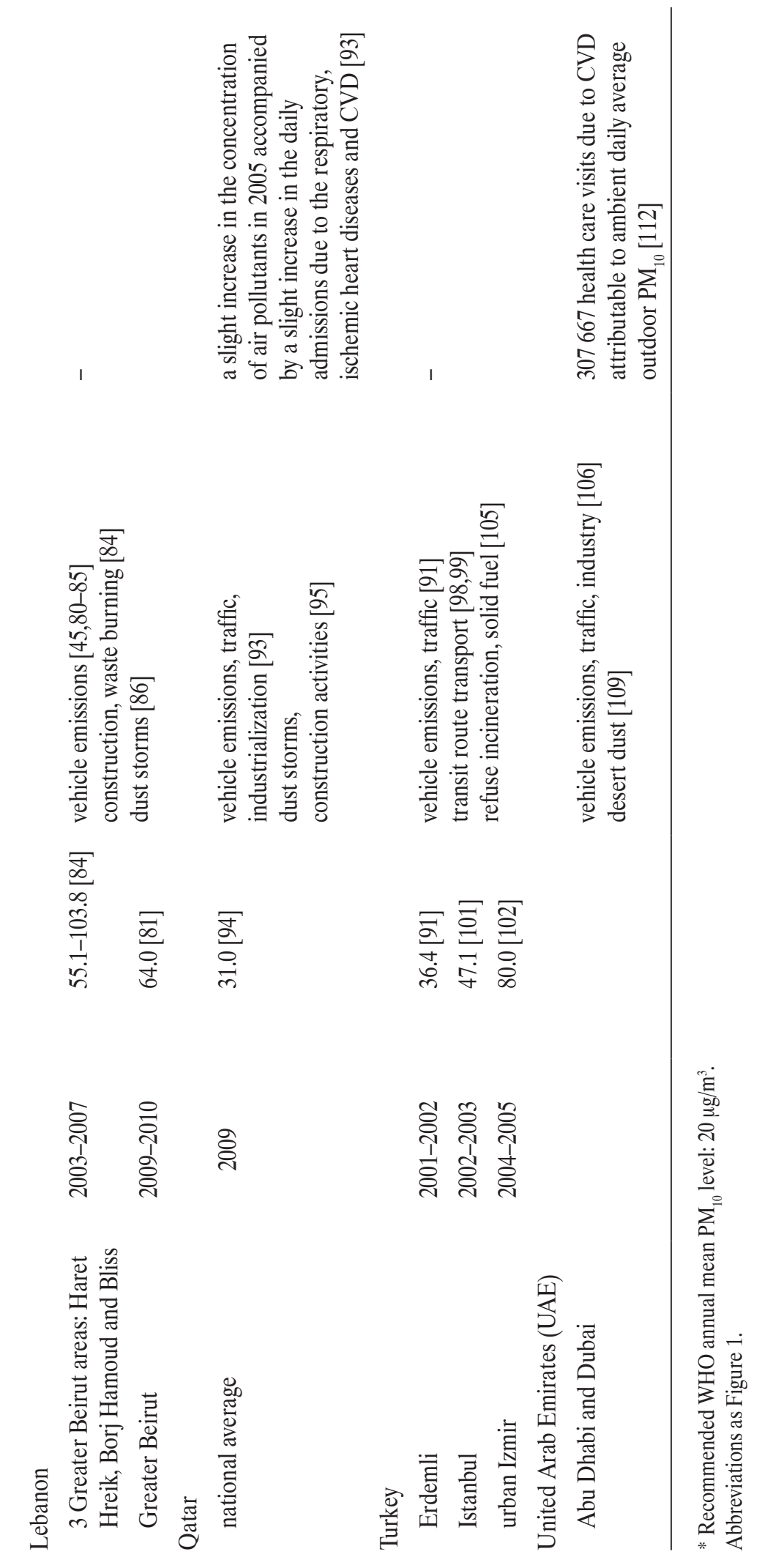


technologies could all have a role in reducing air pollution and its consequences for cardiovascular morbidity and mortality. Our paper should motivate the Middle East government to establish permanent stations for monitoring general air quality across all geographical areas.

\section{REFERENCES}

1. Brunekreef B, Holgate ST. Air pollution and health. Lancet. 2002;360(9341):1233-42, http://dx.doi.org/10.1016/S01406736(02)11274-8.

2. D'Amato G, Cecchi L, D'Amato M, Liccardi G. Urban air pollution and climate change as environmental risk factors of respiratory allergy: An update. J Investig Allergol Clin Immunol. 2010;20(2):95-102.

3. Ballester F, Rodriguez P, Iniguez C, Saez M, Daponte A, Galan I, et al. Air pollution and cardiovascular admissions association in Spain: Results within the EMECAS project. J Epidemiol Community Health. 2006;60(4):328-36, http:// dx.doi.org/10.1136/jech.2005.037978.

4. Mills NL, Donaldson K, Hadoke PW, Boon NA, MacNee W, Cassee FR, et al. Adverse cardiovascular effects of air pollution. Nature Clin Pract Cardiovasc Med. 2009;6(1):36-44, http://dx.doi.org/10.1038/ncpcardio1399.

5. Sun Q, Hong X, Wold LE. Cardiovascular effects of ambient particulate air pollution exposure. Circulation. 2010;121(25): 2755-65, http://dx.doi.org/10.1161/CIRCULATIONAHA. 109.893461.

6. Brook RD, Franklin B, Cascio W, Hong Y, Howard G, Lipsett $\mathrm{M}$, et al. Air pollution and cardiovascular disease: A statement for healthcare professionals from the Expert Panel on Population and Prevention Science of the American Heart Association. Circulation. 2004;109(21):2655-71, http:// dx.doi.org/10.1161/01.CIR.0000128587.30041.C8.

7. Nemmar A, Hoet PH, Vanquickenborne B, Dinsdale D, Thomeer M, Hoylaerts MF, et al. Passage of inhaled particles into the blood circulation in humans. Circulation. 2002;105(4):411-4, http://dx.doi.org/10.1161/hc0402.104118.
8. Nemery B, Hoet PH, Nemmar A. The Meuse Valley fog of 1930: An air pollution disaster. Lancet. 2001;357(9257): 704-8, http://dx.doi.org/10.1016/S0140-6736(00)04135-0.

9. Logan WP. Mortality in the London fog incident, 1952. Lancet. 1953;1(6755):336-8, http://dx.doi.org/10.1016/ S0140-6736(53)91012-5.

10. Schwartz J, Dockery DW. Particulate air pollution and daily mortality in Steubenville, Ohio. Am J Epidemiol. 1992;135(1):12-9.

11. Ozkaynak H, Thurston GD. Associations between 1980 U.S. mortality rates and alternative measures of airborne particle concentration. Risk Anal. 1987;7(4):449-61, http://dx.doi.org/10.1111/j.1539-6924.1987.tb00482.x.

12. Pope CA 3rd, Schwartz J, Ransom MR. Daily mortality and $\mathrm{PM}_{10}$ pollution in Utah Valley. Arch Environ Health. 1992;47(3):211-7, http://dx.doi.org/10.1080/000398 96.1992.9938351.

13. Schwartz J. Particulate air pollution and daily mortality in Detroit. Environ Res. 1991;56(2):204-13, http://dx.doi. org/10.1016/S0013-9351(05)80009-X.

14. Bates DV, Sizto R. Relationship between air pollutant levels and hospital admissions in Southern Ontario. Can J Public Health. 1983;74(2):117-22.

15. Bates DV, Sizto R. Air pollution and hospital admissions in Southern Ontario: The acid summer haze effect. Environ Res. 1987;43(2):317-31, http://dx.doi.org/10.1016/S00139351(87)80032-4.

16. Miller MR, Shaw CA, Langrish JP. From particles to patients: Oxidative stress and the cardiovascular effects of air pollution. Future Cardiol. 2012;8(4):577-602, http://dx.doi. org/10.2217/fca.12.43.

17. Dockery DW, Pope CA 3rd, Xu X, Spengler JD, Ware JH, Fay ME, et al. An association between air pollution and mortality in 6 U.S. cities. N Engl J Med. 1993;329(24): 1753-9, http://dx.doi.org/10.1056/NEJM199312093292401.

18. Hoek G, Brunekreef B, Goldbohm S, Fischer P, van den Brandt PA. Association between mortality and indicators of traffic-related air pollution in the Netherlands: 
A cohort study. Lancet. 2002;360(9341):1203-9, http:// dx.doi.org/10.1016/S0140-6736(02)11280-3.

19. Pope CA 3rd, Burnett RT, Thurston GD, Thun MJ, Calle EE, Krewski D, et al. Cardiovascular mortality and longterm exposure to particulate air pollution: Epidemiological evidence of general pathophysiological pathways of disease. Circulation. 2004;109(1):71-7, http://dx.doi.org/10.1161/01. CIR.0000108927.80044.7F.

20. Pope CA 3rd, Muhlestein JB, May HT, Renlund DG, Anderson JL, Horne BD. Ischemic heart disease events triggered by short-term exposure to fine particulate air pollution. Circulation. 2006;114(23):2443-8, http://dx.doi.org/10.1161/ CIRCULATIONAHA.106.636977.

21. Miller KA, Siscovick DS, Sheppard L, Shepherd K, Sullivan $\mathrm{JH}$, Anderson GL, et al. Long-term exposure to air pollution and incidence of cardiovascular events in women. N Engl J Med. 2007;356(5):447-58, http://dx.doi. org/10.1056/NEJMoa054409.

22. Lopez AD, Mathers CD, Ezzati M, Jamison DT, Murray CJ. Global and regional burden of disease and risk factors, 2001: Systematic analysis of population health data. Lancet. 2006;367(9524):1747-57, http://dx.doi.org/10. 1016/S0140-6736(06)68770-9.

23. Rosamond W, Flegal K, Friday G, Furie K, Go A, Greenlund $\mathrm{K}$, et al. Heart disease and stroke statistics - 2007 update: A report from the American Heart Association Statistics Committee and Stroke Statistics Subcommittee. Circulation. 2007;115(5):28, http://dx.doi.org/10.1161/CIRCULATIONAHA.106.179918.

24. Department of Health And Human Services. The burden of chronic diseases and their risk factors - National and state perspectives. Atlanta (GA): Center for Disease Control, National Center for Chronic Disease Prevention and Health Promotion; 2004 [cited 2013 Dec 12]. Available from: http://9healthfair.publichealthpractice.org/documents/burden_book2004.pdf.

25. Peters A, Dockery DW, Muller JE, Mittleman MA. Increased particulate air pollution and the triggering of myocardial infarction. Circulation. 2001;103(23):2810-5, http://dx.doi. org/10.1161/01.CIR.103.23.2810.

26. Peters A, Frohlich M, Doring A, Immervoll T, Wichmann HE, Hutchinson WL, et al. Particulate air pollution is associated with an acute phase response in men. Results from the MONICA-Augsburg Study. Eur Heart J. 2001;22(14):1198-204, http://dx.doi.org/10.1053/euhj.2000.2483.

27. Nel A. Atmosphere. Air pollution-related illness: Effects of particles. Science. 2005;308(5723):804-6, http://dx.doi. org/10.1126/science.1108752.

28. Zanobetti A, Schwartz J. The effect of particulate air pollution on emergency admissions for myocardial infarction: A multicity case-crossover analysis. Environ Health Perspect. 2005;113(8):978-82.

29. Wellenius GA, Bateson TF, Mittleman MA, Schwartz J. Particulate air pollution and the rate of hospitalization for congestive heart failure among Medicare beneficiaries in Pittsburgh, Pennsylvania. Am J Epidemiol. 2005;161(11): 1030-6, http://dx.doi.org/10.1093/aje/kwi135.

30. Wellenius GA, Schwartz J, Mittleman MA. Particulate air pollution and hospital admissions for congestive heart failure in 7 United States cities. Am J Cardiol. 2006;97(3): 404-8, http://dx.doi.org/10.1016/j.amjcard.2005.08.061.

31. Dominici F, Peng RD, Bell ML, Pham L, McDermott A, Zeger SL, et al. Fine particulate air pollution and hospital admission for cardiovascular and respiratory diseases. JAMA. 2006; 295(10):1127-34, http://dx.doi.org/10.1001/jama.295.10.1127.

32. Simkhovich BZ, Kleinman MT, Kloner RA. Air pollution and cardiovascular injury: Epidemiology, toxicology, and mechanisms. J Am Coll Cardiol. 2008;52(9):719-26, http:// dx.doi.org/10.1016/j.jacc.2008.05.029.

33. Gurgueira SA, Lawrence J, Coull B, Murthy GG, GonzalezFlecha B. Rapid increases in the steady-state concentration of reactive oxygen species in the lungs and heart after particulate air pollution inhalation. Environ Health Perspect. 2002;110(8):749-55.

34. Sharman JE, Coombes JS, Geraghty DP, Fraser DI. Exposure to automotive pollution increases plasma 
susceptibility to oxidation. Arch Environ Health. 2002;57 (6):536-40, http://dx.doi.org/10.1080/00039890209602085.

35. Sorensen M, Daneshvar B, Hansen M, Dragsted LO, Hertel O, Knudsen L, et al. Personal $\mathrm{PM}_{2.5}$ exposure and markers of oxidative stress in blood. Environ Health Perspect. 2003;111(2):161-6.

36. Kim JY, Mukherjee S, Ngo LC, Christiani DC. Urinary 8-hydroxy-2'-deoxyguanosine as a biomarker of oxidative DNA damage in workers exposed to fine particulates. Environ Health Perspect. 2004;112(6):666-71.

37. Vinzents PS, Moller P, Sorensen M, Knudsen LE, Hertel O, Jensen FP, et al. Personal exposure to ultrafine particles and oxidative DNA damage. Environ Health Perspect. 2005;113(11):1485-90.

38. Rhoden CR, Wellenius GA, Ghelfi E, Lawrence J, Gonzalez-Flecha B. PM-induced cardiac oxidative stress and dysfunction are mediated by autonomic stimulation. Biochim Biophys Acta. 2005;10(3):305-13, http://dx.doi.org/ 10.1016/j.bbagen.2005.05.025.

39. Brauner EV, Forchhammer L, Moller P, Simonsen J, Glasius $\mathrm{M}$, Wahlin $\mathrm{P}$, et al. Exposure to ultrafine particles from ambient air and oxidative stress-induced DNA damage. Environ Health Perspect. 2007;115(8):1177-82.

40. Gong KW, Zhao W, Li N, Barajas B, Kleinman M, Sioutas $\mathrm{C}$, et al. Air-pollutant chemicals and oxidized lipids exhibit genome-wide synergistic effects on endothelial cells. Genome Biol. 2007;8(7):R149, http://dx.doi.org/10.1186/gb2007-8-7-r149.

41. Goto Y, Hogg JC, Shih CH, Ishii H, Vincent R, van Eeden SF. Exposure to ambient particles accelerates monocyte release from bone marrow in atherosclerotic rabbits. Am J Physiol Lung Cell Mol Physiol. 2004;287(1): L79-85, http://dx.doi.org/10.1152/ajplung.00425.2003.

42. Ruckerl R, Greven S, Ljungman P, Aalto P, Antoniades C, Bellander T, et al. Air pollution and inflammation (interleukin-6, C-reactive protein, fibrinogen) in myocardial infarction survivors. Environ Health Perspect. 2007;115(7): 1072-80.
43. Chuang KJ, Chan CC, Su TC, Lee CT, Tang CS. The effect of urban air pollution on inflammation, oxidative stress, coagulation, and autonomic dysfunction in young adults. Am J Respir Crit Care Med. 2007;176(4):370-6, http:// dx.doi.org/10.1164/rcem.200611-16270C.

44. Lelieveld J, Hoor P, Jackel P, Pozzer A, Hadjinocolau P, Cammas JP, et al. Severe ozone air pollution in the Persian Gulf region. Atmos Chem Phys. 2009 [cited 2015 Apr 30];9(4):1393-406. Available from: http://www. atmos-chem-phys.net/9/1393/2009/acp-9-1393-2009.pdf.

45. Saliba NA, Massoud R. A comparative review of PM levels, sources, and their likely fates in the eastern Mediterranean region. In: Zereini F, Wisseman CLS, editors. Urban airborne particulate matter. Environmental science and engineering. Berlin Heidelberg: Springer; 2010. pp. 3-17, http:// dx.doi.org/10.1007/978-3-642-12278-1_1.

46. Akbari S. Dust storms, sources in the Middle East and economic models for survey its impacts. Aust J Basic Appl Sci. 2011;5(12):227.

47. United States Census Bureau International Data Base Internet. United States Census Bureau. World population; 2009 [cited 2013 Aug 16]. Available from: http://www. census.gov/population/international/data/worldpop/table_ population.php.

48. Saliba N, Kouyoumijian H, Roumié M. Effect of local and long-range transport emission on the elemental composition of $\mathrm{PM}_{10-2.5}$ and $\mathrm{PM}_{2.5}$ in Beirut. Atmos Environ. 2007;41(31):6497-509, http://dx.doi.org/10.1016/j.atmosenv.2007.04.032.

49. Kanakidou M, Mihalopoulos N, Kindap T, Im U, Vrekoussis M, Gerasopoulo E. Megacities as hot spots of air pollution in the East Mediterranean. Atmos Environ. 2011;45:1223-35, http://dx.doi.org/10.1016/j.atmosenv. 2010.11.048.

50. Abu-Allaban M, Gertler AW, Lowenthal DH. A preliminary apportionment of the sources of ambient $\mathrm{PM}_{10}$, $\mathrm{PM}_{2.5}$ and VOCs in Cairo. Atmos Environ. 2002;36(35): 5549-57, http://dx.doi.org/10.1016/S1352-2310(02)00662-3. 
51. Abu-Allaban M, Lowenthal D, Gertler A, Labib M. Sources of $\mathrm{PM}_{10}$ and $\mathrm{PM}_{2.5}$ in Cairo's ambient air. Environ Monit Assess. 2007;133(1-3):417-25, http://dx.doi.org/10.1007/s106 61-006-9596-8.

52. Moussa M, Abdelkhalek A. Meteorological analysis for black cloud (episodes) formation and its monitoring by remote sensing. J Appl Sci Res. 2007;3(2):147-54.

53. Country cooperation strategy for WHO and Egypt 20102014. Geneva: World Health Organization; 2010 [cited 2013 Dec 11]. Available from: http://www.who.int/countryfocus/ cooperation_strategy/ccs_egy_en.pdf.

54. World Health Organization. Air quality guidelines for particulate matter, ozone, nitrogen dioxide and sulfur dioxide. Global update 2005. Summary of risk assessment. Geneva: WHO; 2006 [cited 2013 Nov 12]. Available from: http://whqlibdoc.who.int/hq/2006/WHO_SDE_PHE_OEH_06.02_eng.pdf.

55. Zakey AS, Abedl-Wahab MM, Pettersson JBC, Gatari MJ, Halliquist M. Seasonal and spatial variation of atmospheric particulate matter in a developing mega city, the Greater Cairo, Egypt. Atmósfera. 2008;21(2):171-89.

56. Watson J, Lu Z, Fujita E, Lowenthal D, Lawson D. Chemical mass balance source apportionment of $\mathrm{PM}_{10}$ during the Southern California Air Quality Study. Aerosol Sci Technol. 1994;4(21):1-36, http://dx.doi.org/ 10.1080/02786829408959693.

57. Watson J, Robinson N, Chow J, Henry R, Kim B, Pace T, et al. The USEPA/DRI chemical mass balance receptor model, CMB 7.0. Environ Softw. 1990;5:38-49, http://dx.doi.org/10.1016/0266-9838(90)90015-X.

58. Madanipour A. Urban planning and development in Tehran. Cities. 2006;23(6):433-8, http://dx.doi.org/10.1016/ j.cities.2006.08.002.

59. Atash F. The deterioration of urban environments in developing countries: Mitigating the air pollution crisis in Tehran, Iran. Cities. 2007;24:399-409, http://dx.doi.org/10. 1016/j.cities.2007.04.001.

60. Naddafi K, Sowlat M, Safari M. Integrated assessment of air pollution in Tehran, over the period from September
2008 to September 2009. Iran J Public Health. 2012; 41(2):77-86.

61. Halek F, Kianpour-Rad M, Kavousirahim A. Seasonal variation in ambient PM mass and number concentrations (case study: Tehran, Iran). Environ Monit Assess. 2010;169 (1-4):501-7, http://dx.doi.org/10.1007/s10661-009-1192-2.

62. Urban outdoor air pollution database. Geneva: World Health Organization; 2011 [cited 2013 Nov 15]. Available from: http://www.who.int/mediacentre/factsheets/fs 313/en.

63. Naddafi K, Hassanvand MS, Yunesian M, Momeniha F, Nabizadeh R, Faridi S, et al. Health impact assessment of air pollution in megacity of Tehran, Iran. Iranian J Environ Health Sci Eng. 2012;9(1):1735-2746.

64. Poursafa P, Kelishadi R. Air pollution, platelet activation and atherosclerosis. Inflamm Allergy Drug Targets. 2010;9(5):387-92, http://dx.doi.org/10.2174/18715281 0793937982.

65. Davoodi G, Sharif AY, Kazemisaeid A, Sadeghian S, Farahani AV, Sheikhvatan M, et al. Comparison of heart rate variability and cardiac arrhythmias in polluted and clean air episodes in healthy individuals. Environ Health Prev Med. 2010;15(4):217-21, http://dx.doi.org/10.1007/s12199009-0130-9.

66. Poursafa P, Kelishadi R, Lahijanzadeh A, Modaresi M, Javanmard SH, Assari R, et al. The relationship of air pollution and surrogate markers of endothelial dysfunction in a population-based sample of children. BMC Public Health. 2011;11(115):1471-2458, http://dx.doi.org/10. 1186/1471-2458-11-115.

67. Krzyzanowski M. Methods for assessing the extent of exposure and effects of air pollution. Occup Environ Med. 1997;54:145-51, http://dx.doi.org/10.1136/oem. 54.3.145.

68. Alnawaiseh NA, Hashim JH, Md Isa Z. Relationship between vehicle count and particulate air pollution in Amman, Jordan. Asia Pac J Public Health. 2015;27(2):NP 1742-51, http://dx.doi.org/10.1177/1010539512455046. 
69. Jamrah A, Al-Omari A, Sharabi R. Evaluation of traffic noise pollution in Amman, Jordan. Environ Monit Assess. 2006;120(1-3):499-525, http://dx.doi.org/10.1007/ s10661-005-9077-5.

70. Khodeir M, Shamy M, Alghamdi M, Zhong M, Sun H, Costa $\mathrm{M}$, et al. Source apportionment and elemental composition of $\mathrm{PM}_{2.5}$ and $\mathrm{PM}_{10}$ in Jeddah City, Saudi Arabia. Atmos Pollut Res. 2012;3(3):331-40, http://dx.doi.org/10.5094/APR.2012.037.

71. Maciejczyk P, Chen LC. Effects of subchronic exposures to concentrated ambient particles (CAPs) in mice. VIII. Source-related daily variations in in vitro responses to CAPs. Inhal Toxicol. 2005;17(4-5):243-53.

72. Rushdi A, Al-Mutlaq K, Al-Otaibi M, El-Mubarak A, Simoneit B. Air quality and elemental enrichment factors of aerosol particulate matter in Riyadh City, Saudi Arabia. Arab J Geosci. 2013;6(2):585-99, http://dx.doi.org/10.1007/ s12517-011-0357-9.

73. Sun H, Shamy M, Kluz T, Munoz AB, Zhong M, Laulicht F, et al. Gene expression profiling and pathway analysis of human bronchial epithelial cells exposed to airborne particulate matter collected from Saudi Arabia. Toxicol Appl Pharmacol. 2012;265(2):147-57, http://dx.doi.org/10.1016/ j.taap.2012.10.008.

74. Krupa M. Environmental and economic repercussions of the Persian Gulf War on Kuwait. ICE Case Studies; 1997 [cited 2013 Nov 12]. Available from: http://www1.american. edu/ted/ice/kuwait.htm.

75. Alolayan MA, Brown KW, Evans JS, Bouhamra WS, Koutrakis P. Source apportionment of fine particles in $\mathrm{Ku}-$ wait City. Sci Total Environ. 2013;448:14-25, http://dx.doi. org/10.1016/j.scitotenv.2012.11.090.

76. Brown KW, Bouhamra W, Lamoureux DP, Evans JS, Koutrakis P. Characterization of particulate matter for 3 sites in Kuwait. J Air Waste Manag Assoc. 2008;58(8): 994-1003, http://dx.doi.org/10.3155/1047-3289.58.8.994.

77. Alsalem SM. An overview of the pollution of $\mathrm{PM}_{10}$ pollution problem in Fahaheel urban area, Kuwait. Emirates J Eng Res. 2008;13(3):1-9.
78. Grivas G, Chaloulakou A, Kassomenos P. An overview of the $\mathrm{PM}_{10}$ pollution problem, in the Metropolitan Area of Athens, Greece. Assessment of controlling factors and potential impact of long range transport. Sci Total Environ. 2008;389(1): 165-77, http://dx.doi.org/10.1016/j.scitotenv.2007.08.048.

79. Al-Rifaia N, Elmi A, Khan A. Exploring possible seasonal trends in mortality rate in relation to age, gender and environmental conditions in Kuwait: A preliminary analysis. J Eng Res. 2011;8(1):19-27.

80. Chaaban FB, Ayoub GM, Oulabi M. A preliminary evaluation of selected transport-related pollutants in the ambient atmosphere of the city of Beirut, Lebanon. Water Air Soil Pollut. 2001;126:53-62, http://dx.doi. org/10.1023/A:1005202716880.

81. Massoud R, Shihade A, Roumie M, Youness M, Gerard J, Saliba N. Intra urban variability of $\mathrm{PM}_{10}$ and $\mathrm{PM}_{2.5}$ in eastern Mediterranean city. Atmos Res. 2011;101:893-901, http:// dx.doi.org/10.1016/j.atmosres.2011.05.019.

82. Ministry of Environment. Lebanon: National environmental action plan; 2010 [cited 2013 Nov 12]. Available from: http:// test.moe.gov.lb/Documents/SOER\%20chap $\% 204 \% 20$ reduced.pdf.

83. Saliba N, Moussa S, Salame H, El-Fadel M. Variation of the selected air quality indicators over the city of Beirut, Lebanon: Assessment of regional and local emission sources. Atmos Environ. 2006;40(18):3263-8, http://dx.doi. org/10.1016/j.atmosenv.2006.01.054.

84. Saliba N, El Jam F, El Tayar G, Obeid W, Roumie M. Origin and variability of particulate matter $\left(\mathrm{PM}_{10}\right.$ and $\mathrm{PM}_{2.5}$ ) mass concentrations over an Eastern Mediterranean city. Atmos Res. 2010;97:106-14, http://dx.doi.org/10. 1016/j.atmosres.2010.03.011.

85. Waked A, Afif C. Emissions of air pollutants from road transport in Lebanon and other countries in the Middle East region. Atmos Environ. 2012;61:446-52, http://dx.doi. org/10.1016/j.atmosenv.2012.07.064.

86. Kubilay N, Nickovic S, Moulin C, Dulac F. An illustration of the transport and deposition of mineral dust onto 
the eastern Mediterranean. Atmos Environ. 2000;34:1293303, http://dx.doi.org/10.1016/S1352-2310(99)00179-X.

87. Shaka H, Saliba N. Concentration measurements and chemical composition of $\mathrm{PM}_{10-2.5}$ and $\mathrm{PM}_{2.5}$ at a coastal site in Beirut, Lebanon. Atmos Environ. 2004;38:523-31, http://dx.doi.org/10.1016/j.atmosenv.2003.10.009.

88. Mcfarland A, Ortiz C, Bertch R. Particle collection characteristics of single-stage dichotomous sampler. Environ Sci Technol. 1978;12:679-82, http://dx.doi.org/10.1021/es 60142a006.

89. Abu-Allaban M, Hamasha S, Gertler A. Road dust resuspension in the vicinity of limestone quarries in Jordan. J Air Waste Manag Assoc. 2006;56(10):1440-4, http://dx. doi.org/10.1080/10473289.2006.10464546.

90. Freimna MT, Hirshel N, Broday DM. Urban-scale variability of ambient particulate matter attributes. Atmos Environ. 2006;40:5670-84, http://dx.doi.org/10.1016/ j.atmosenv.2006.04.060.

91. Koçak M, Mihalopoulos N, Kubaily N. Contributions of natural sources to high $\mathrm{PM}_{10}$ and $\mathrm{PM}_{2.5}$ events in the eastern Mediterranean. Atmos Environ. 2007;41:3806-18.

92. Querol X, Alastuey A, Rodriguez S, Plana F, Ruiz CR, Cots N. $\mathrm{PM}_{10}$ and $\mathrm{PM}_{2.5}$ source apportionment in the Barcelona Metropolitan area, Catalonia, Spain. Atmos Environ. 2001;35:6407-19, http://dx.doi.org/10.1016/S13522310(01)00361-2.

93. Bener A, Dogan M, Ehlayel MS, Shanks NJ, Sabbah A. The impact of air pollution on hospital admission for respiratory and cardiovascular diseases in an oil and gas-rich country. Eur Ann Allergy Clin Immunol. 2009; 41(3):80-4.

94. Qatar Statistics Authority. Qatar: Leaving a legacy for future generations. Progress, challenges and responses for sustainable development; 2012 [cited: 2013 Nov 12]. Available from: http://www.gsdp.gov.qa/portal/page/portal/gsdp_en/ knowledge_center/Tab2/Qatar\%20Leaving\%20a\%20Legacy $\% 20$ for $\% 20$ Future $\% 20$ Generations_Final $\% 2010 w \% 20$ res-21-11-2012.pdf.
95. World Bank. Ambient particulate matter concentrations in residential and pollution hotspot areas of world cities: New estimates based on the Global Model of Ambient Particulates (GMAPS). Development Research Group and Environment Department [cited 2013 Dec 12]. Available from: http://wdi.worldbank.org/table/3.13.

96. Meslmani Y. Some trends related to air pollution in Damascus. Manag Environ Qual. 2004;15(4):353-63, http:// dx.doi.org/10.1108/14777830410540108.

97. Tayanc M, Im U, Dorguel M, Karaca M. Climate change in Turkey for the last half century. Clim Change. 2009;94: 483-502, http://dx.doi.org/10.1007/s10584-008-9511-0.

98. Karaka F, Camci F. Distant source contributions to $\mathrm{PM}_{10}$ profile evaluated by SOM based cluster analysis of air mass trajectory sets. Atmos Environ. 2010;44:892-9, http://dx.doi.org/10.1016/j.atmosenv.2009.12.006.

99. Kindap T, Unal A, Chen S, Hu Y, Odman M, Karaca M. Long-range aerosol transport from Europe to Istanbul, Turkey. Atmos Environ. 2006;40:3536-47, http://dx.doi.org/ 10.1016/j.atmosenv.2006.01.055.

100. Hopke P, Xie Y, Raunemaa T, Biegalski S, Landsberger S, Maenhaut W, et al. Characterization of the gent stacked filter unit $\mathrm{PM}_{10}$ sampler. Aerosol Sci Technol. 1997;27: 726-35, http://dx.doi.org/10.1080/02786829708965507.

101. Karaca F, Alagha O, Erturk F. Statistical characterization of atmospheric $\mathrm{PM}_{10}$ and $\mathrm{PM}_{2.5}$ concentrations at a non-impacted suburban site of Istanbul, Turkey. Chemosphere. 2005;59(8):1183-90, http://dx.doi.org/10.1016/ j.chemosphere.2004.11.062.

102. Yatkin S, Bayram A. Source apportionment of $\mathrm{PM}_{10}$ and $\mathrm{PM}_{2.5}$ using positive matrix factorization and chemical mass balance in Izmir, Turkey. Sci Total Environ. 2008;390(1):109-23, http://dx.doi.org/10.1016/j.scitotenv.2007.08.059.

103. Theodosi C, Im U, Bougiatioti A, Zarmpas P, Yenigun $\mathrm{O}$, Mihalopoulos N. Aerosol chemical composition over Istanbul. Sci Total Environ. 2010;408(12):2482-91, http://dx.doi.org/10.1016/j.scitotenv.2010.02.039. 
104. Bardouki H, Liakakou H, Economou C, Sciare J, Smolik J, Zdimal V, et al. Chemical composition of size resolved atmospheric aerosols in the eastern Mediterranean during summer and winter. Atmos Environ. 2003;37:195-208, http://dx.doi.org/10.1016/S1352-2310(02)00859-2.

105. Koçak M, Theodosi Ch, Theodosi C, Zarmpas P, Im U, Bougiatioti A, et al. Particulate matter $\left(\mathrm{PM}_{10}\right)$ in Istanbul: Origin, source areas and potential impact on surrounding regions. Atmos Environ. 2011;45:6891-900, http://dx.doi. org/10.1016/j.atmosenv.2010.10.007.

106. Li Y, Gibson JM, Jat P, Puggioni G, Hasan M, West JJ, et al. Burden of disease attributed to anthropogenic air pollution in the United Arab Emirates: Estimates based on observed air quality data. Sci Total Environ. 2010;408(23): 5784-93, http://dx.doi.org/10.1016/j.scitotenv.2010.08.017.

107. Cassen RH. Current trends in population change and their causes. Popul Dev Rev. 1978;4(2):331-53, http://dx.doi. org/10.2307/1972285.

108. United Nations. New York: World Population Prospects: The 2006 Revision, Highlights. Department of Economic and Social Affairs, Population Division; 2007 [cited 2013 May 25]. Available from: http://www.un.org/esa/population/publications/wpp2006/WPP2006_Highlights_rev.pdf.

109. Statistics Centre of Abu Dhabi. United Arab Emirates: Annual bulletin of climate and air statistics; 2011 [cited 2013 Nov 19]. Available from: https:www.abudhabi.ae/pdfdirectview/en/308788/blaetterkatalog/blaetterkatalog/pdf/complete.pdf.

110. Aljallad F, Al-Katheeri E, Al-Omar M. Concentrations of particulate matter and their relationships with meteorological variables. Sustain Environ Res. 2013;23(3):191-8.

111. Country profiles of environmental burden of disease: United Arab Emirates. Geneva: World Health Organization; 2009 [cited $2013 \mathrm{Jul}$ 23]. Available at: http://www.who.int/ quantifying_ehimpacts/national/countryprofile/unitedarabemirates.pdf.

112. MacDonald Gibson J, Thomsen J, Launay F, Harder E, DeFelice N. Deaths and medical visits attributable to environmental pollution in the United Arab Emirates. PLoS One. 2013;8(3):4, http://dx.doi.org/10.1371/ journal.pone.0057536.

113. Ostro B. Outdoor air pollution: Assessing the environmental burden of disease at national and local levels. Geneva: World Health Organization; 2004 [cited 2013 Oct 18]. Available from: www.who.int/quantifying_ehimpacts/publications/ebd5.pdf.

114. Abu-Allaban M, Gillies JA, Gertler AW, Clayton R, Proffitt D. Motor vehicle contributions to ambient $\mathrm{PM}_{10}$ and $\mathrm{PM}_{2.5}$ at selected urban areas in the USA. Environ Assess. 2007;132(1-3):155-63, http://dx.doi.org/10.1007/ s10661-006-9511-3.

115. Baalbaki R, Al-Assaad K, Mehanna CJ, Saliba NA, Katurji M, Roumie M. Road versus roadside particle size distribution in a hot Mediterranean summer - Estimation of fleet emission factors. J Air Waste Manag Assoc. 2013;63(3): 327-35, http://dx.doi.org/10.1080/10962247.2012.761660.

116. Economic and Social Commission for Western Asia. Transport for sustainable development for the Arab Region: Measures, progress achieved challenge and policy framework. New York: United Nations; 2010 [cited 2013 Aug 12]. Available from: http://www.escwa.un.org/information/publications/edit/upload/SDPD-09-wp-1.pdf.

117. United Nations Environmental Program. Paris: United Nations Environmental Program [cited 2013 Aug 18]. Urban air pollution. Available from: http://www.unep.org/ urban_environment/issues/urban_air.asp.

118. Maheswaran R, Elliott P. Stroke mortality associated with living near main roads in England and Wales: A geographical study. Stroke. 2003;34(12):2776-80, http://dx.doi. org/10.1161/01.STR.0000101750.77547.11.

119. Tonne C, Melly S, Mittleman M, Coull B, Goldberg R, Schwartz J. A case-control analysis of exposure to traffic and acute myocardial infarction. Environ Health Perspect. 2007;115(1):53-7.

120. Adar SD, Kaufman JD. Cardiovascular disease and air pollutants: Evaluating and improving epidemiological data 
implicating traffic exposure. Inhal Toxicol. 2007;1:135-49, http://dx.doi.org/10.1080/08958370701496012.

121. Araujo JA, Barajas B, Kleinman M, Wang X, Bennett BJ, Gong KW, et al. Ambient particulate pollutants in the ultrafine range promote early atherosclerosis and systemic oxidative stress. Circ Res. 2008;102(5):589-96, http:// dx.doi.org/10.1161/CIRCRESAHA.107.164970.

122. Kunzli N, Jerrett M, Mack WJ, Beckerman B, LaBree L, Gilliland $\mathrm{F}$, et al. Ambient air pollution and atherosclerosis in Los Angeles. Environ Health Perspect. 2005;113(2):201-6.

123. Pope CA 3rd, Verrier RL, Lovett EG, Larson AC, Raizenne ME, Kanner RE, et al. Heart rate variability associated with particulate air pollution. Am Heart J. 1999;138(5 Pt 1):890-9, http://dx.doi.org/10.1016/ S0002-8703(99)70014-1.

124. Gold DR, Litonjua A, Schwartz J, Lovett E, Larson A, Nearing B, et al. Ambient pollution and heart rate variability. Circulation. 2000;101(11):1267-73, http://dx.doi. org/10.1161/01.CIR.101.11.1267.

125. Fung KY, Luginaah I, Gorey KM, Webster G. Air pollution and daily hospital admissions for cardiovascular diseases in Windsor, Ontario. Can J Public Health. 2005;96(1):29-33.

126. Chang CC, Tsai SS, Ho SC, Yang CY. Air pollution and hospital admissions for cardiovascular disease in
Taipei, Taiwan. Environ Res. 2005;98(1):114-9, http:// dx.doi.org/10.1016/j.envres.2004.07.005.

127. Maheswaran R, Haining RP, Brindley P, Law J, Pearson T, Fryers PR, et al. Outdoor air pollution, mortality, and hospital admissions from coronary heart disease in Sheffield, UK: A small-area level ecological study. Eur Heart J. 2005;26(23):2543-9, http://dx.doi.org/10.1093/eurheartj/ehi457.

128. Yang CY. Air pollution and hospital admissions for congestive heart failure in a subtropical city: Taipei, Taiwan. J Toxicol Environ Health A. 2008;71(16):1085-90, http://dx.doi.org/10.1080/15287390802114428.

129. European Environment Agency. EEA signals 2013. Every breath we take: Improving air quality in Europe. Copenhagen: The Agency; 2013.

130. World Health Organization. Public health policy for outdoor air quality. Geneva: WHO; 2015 [cited 2013 Sep 26]. Available from: http://www.who.int/phe/health_ topics/outdoorair/databases/public_health_policy/en/ index3.html.

131. Environmental Protection Agency. Air Quality Index (AQI): A guide to air quality and your health [cited 2013 Sep 15]. Available from: http://airnow.gov/index. $\mathrm{cfm}$ ?action=aqibasics.aqi.

This work is available in Open Access model and licensed under a Creative Commons Attribution-NonCommercial 3.0 Poland License - http://creativecommons.org/ licenses/by-nc/3.0/pl/deed.en. 